\title{
Early Transplantation into a Vesicostomy: A Safe Approach For Managing Patients With Severe Obstructive Lesions Who Are Not Candidates For Bladder Augmentation
}

\author{
Aravind Viswanathan ${ }^{\mathrm{a}}$, Thomas Leffler ${ }^{\mathrm{b}}$, Neil Paloian ${ }^{\mathrm{c}}$, Mark Cain ${ }^{\mathrm{d}}$, Patrick H. McKenna ${ }^{\mathrm{e}}$ \\ Author affiliations: \\ ${ }^{a}$ Department of Urology, Division of Pediatric Urology, UW School of Medicine and Public \\ Health; $3^{\text {rd }}$ Floor MFCB, 1685 Highland Ave, Madison, WI 53705; \\ aravind.viswanathan.2012@gmail.com \\ ${ }^{\mathrm{b}}$ Corresponding author; Department of Urology, Division of Pediatric Urology, UW School of
} Medicine and Public Health; $3^{\text {rd }}$ Floor MFCB, 1685 Highland Ave, Madison, WI 53705; leffler@urology.wisc.edu

${ }^{c}$ Department of Pediatrics, Division of Nephrology, UW School of Medicine and Public Health; 600 Highland Ave, Madison, WI 53792; njpaloian@pediatrics.wisc.edu

${ }^{\mathrm{d}}$ Department of Urology, Division of Pediatric Urology, Riley Hospital for Children at Indiana University Health; 705 Riley Hospital Dr, Indianapolis, IN 46202; mpcain@iupui.edu

${ }^{\mathrm{e}}$ Department of Urology, Division of Pediatric Urology, UW Schøøl of Medicine and Public Health; $3^{\text {rd }}$ Floor MFCB, 1685 Highland Ave, Madison, WI 53705; mckenna@urology.wisc.edu

\section{Acknowledgements}

The authors would like to thank the UW Department of Urology, UW Department of Pediatrics, and IUPUI Department of Urology for their research facilitation.

\section{Ethical Approval}

Each institution had IRB approval granted as follows:

University of Wisconsin School of Medicine and Public Health IRB\# 2014-0091 (patients A, B, and C)

Indiana University School of Medicine IRB\# 1605024102 (patients D and E)

This is the author's manuscript of the article published in final edited form as:

Viswanathan, A., Leffler, T., Paloian, N., Cain, M., \& McKenna, P. H. (2018). Early Transplantation into a Vesicostomy: A Safe Approach For Managing Patients With Severe Obstructive Lesions Who Are Not Candidates For Bladder Augmentation. Journal of pediatric urology. https://doi.org/10.1016/j.jpurol.2018.07.022 


\section{Summary}

\section{Introduction}

Management of severe antenatally detected oligohydramnios with and without obstruction is improving with the result that more fetuses are surviving with early renal failure. Significant advances have occurred in all specialties involved in the management of these patients. All of these specialties working together have resulted in the survival of more patients born in renal failure.

\section{Objective}

The aim of this study is to highlight the medical advances in antenatal management of fetal oligohydramnios and pulmonary hypoplasia and to demonstrate that transplantation into a diverted urinary system is safe and leads to good outcomes.

\section{Study Design}

We present a case series of five patients who, at our respective facilities, recently underwent renal transplantation into bladders drained by cutaneous vesicostomy after extensive bladder evaluation and whose clinical cases highlight the aim of this study.

\section{Results}




\begin{tabular}{|c|c|c|c|c|c|}
\hline Cause of renal failure & Posterior Urethral Valves & $\begin{array}{l}\text { Eagle-Barrett } \\
\text { syndrome }\end{array}$ & Posterior Urethral Valves & $\begin{array}{c}\text { Posterior } \\
\text { Urethral Valves }\end{array}$ & $\begin{array}{c}\text { Posterior } \\
\text { Urethral } \\
\text { Valves }\end{array}$ \\
\hline Antenatal interventions & $\begin{array}{l}\text { Amnio-infusions; Attempted } \\
\text { bladder shunt }\end{array}$ & None & None & None & None \\
\hline $\begin{array}{c}\text { Pulmonary } \\
\text { hypoplasia/ventilator } \\
\text { dependency }\end{array}$ & $\begin{array}{l}\text { Yes. ventilation dependency } \\
\text { until } 24 \text { months , requiring } \\
\text { tracheostomy }\end{array}$ & $\begin{array}{l}\text { Ventilator } \\
\text { dependence for } \\
\text { the first few } \\
\text { months of life }\end{array}$ & None & $\begin{array}{c}\text { Yes, Ventilator } \\
\text { dependence for } \\
\text { first few months } \\
\text { of life }\end{array}$ & None \\
\hline Dialysis dependency & $\begin{array}{c}\text { Yes, was on peritoneal dialysis } \\
\text { until transplantation }\end{array}$ & No & No & $\begin{array}{l}\text { Yes, Peritoneal } \\
\text { Dialysis }\end{array}$ & $\begin{array}{c}\text { Yes, } \\
\text { Peritoneal } \\
\text { Dialysis } \\
\end{array}$ \\
\hline \begin{tabular}{|c|}
$\begin{array}{c}\text { Age at transplantation to } \\
\text { diverted vesicostomy }\end{array}$ \\
\end{tabular} & 20 months & 24 months & 26 months & 46 months & 61 months \\
\hline \begin{tabular}{|c|} 
Pre-transplant bladder \\
capacity and compliance
\end{tabular} & $30 \mathrm{~mL}$; poorly compliant & $\begin{array}{l}\text { 45mL; poorly } \\
\text { compliant }\end{array}$ & $10 \mathrm{~mL}$; poorly compliant & $\begin{array}{c}72 \mathrm{~mL} ; \text { poorly } \\
\text { compliant }\end{array}$ & \begin{tabular}{|l}
$26 \mathrm{~mL} ;$ poor \\
compliance
\end{tabular} \\
\hline $\begin{array}{c}\text { Follow-up in months since } \\
\text { transplant }\end{array}$ & 12 months & 12 months & 3 months & 16 months & 64 months \\
\hline $\begin{array}{c}\text { Creatinine prior to } \\
\text { transplant }\end{array}$ & $3.6-5.6$ & $2.2-3.3$ & $1.9-2.8$ & 4.08 & $3.2-3.7$ \\
\hline \begin{tabular}{|c|}
$\begin{array}{c}\text { Creatinine range during } \\
\text { follow-up period }\end{array}$ \\
\end{tabular} & $0.17-0.36$ & $0.13-0.38$ & $0.17-0.34$ & 0.35 & $0.30-0.53$ \\
\hline $\begin{array}{c}\text { Episodes of UTI since } \\
\text { transplant }\end{array}$ & Yes, multiple & None & $\begin{array}{l}\text { Yes, E.coli pyelonephritis } \sim 2 \\
\text { months after transplant }\end{array}$ & None & None \\
\hline $\begin{array}{l}\text { Evidence of transplant } \\
\text { rejection }\end{array}$ & \begin{tabular}{|c|} 
Banff Type IA acute T-cell \\
mediated rejection noted $\sim 2$ \\
months after transplant; but has \\
had multiple subsequent \\
biopsies negative for rejection \\
\end{tabular} & None to date & None to date & None & None \\
\hline $\begin{array}{l}\text { Surgical revision of } \\
\text { vesicostomy or any } \\
\text { subsequent procedures }\end{array}$ & $\begin{array}{c}\text { Yes, revision of vesicostomy } 2 \\
\text { months after transplant \& } \\
\text { balloon dilation of UVJ } \\
\text { anastomosis } 3 \text { months after } \\
\text { transplant }\end{array}$ & None & $\begin{array}{c}\text { None after the } \\
\text { transplant/vesicostomy but patient } \\
\text { had bilateral end cutaneous } \\
\text { ureterostomies done at } 6 \text { days of } \\
\text { age }\end{array}$ & None & None \\
\hline
\end{tabular}




\section{Discussion}

Vesicostomy is an especially attractive option to manage children with small bladders in order to accommodate the high urinary output that occurs post-transplant in infants that require an adult kidney. Recent advances in antenatal management such as amnio-infusion for oligohydramnios have made significant impacts in pulmonary and renal management of this patient population over recent years.

\section{Conclusion}

This report provides further support for the use of vesicostomy as an option for surgical management of patients with renal failure with oligohydramnios and severe obstructive lesions identified antenatally. It also indicates the need to update the criteria for antenatal management of oligohydramnios in obstructive and anephric patients.

Keywords: oligohydramnios; vesicostomy; renal transplant; autoinfusion; urinary diversion; pulmonary hypoplasia 


\section{Introduction}

Management of severe antenatally detected oligohydramnios with and without obstruction is improving with the result that more fetuses are surviving with early renal failure [1]. Significant advances have occurred in all specialties involved in the management of these patients. Maternal fetal obstetricians are becoming more successful with antenatal intervention and beginning to understand the role of autoinfusion in improving pulmonary function [2]. Pediatric nephrologists are able to dialyze infants successfully for an extended period of time and pediatric pulmonary specialists have developed successful methods of managing severe pulmonary hypoplasia including prolonged ventilator support after hospital discharge [3] [4]. Neonatal intensive care units located within children's hospitals can manage the large number of specialties involved in the care of these very sick infants. Children who are surviving with renal failure are often transplanted as soon as they are big enough to receive a donor kidney and with newer immunosuppression regimens, their outcomes are generally excellent. [5]

Multiple specialties working together has resulted in the survival of more patients born in renal failure. Historically, pediatric transplants were not performed into diverted urinary systems, with children instead undergoing undiversion surgeries prior to transplantation due to anecdotal concerns for increased risks for infection, and as such, decreased graft survival [6]. This approach is changing as more transplants are occurring at young ages, making continent diversions difficult; in addition, augmentation may be contraindicated in certain medical conditions. Vesicostomies are an attractive option in these infants because of the need to manage high initial output of adult kidneys placed in small infants. We hypothesized that transplant could be successfully accomplished in patients with vesicostomies. 
The aim of this study is to highlight the medical advances in antenatal management of fetal oligohydramnios and pulmonary hypoplasia and to demonstrate that transplantation into a diverted urinary system is safe and leads to good outcomes.

\section{Materials and Methods}

We present here a case series of five patients who recently underwent renal transplantation into vesicostomies after extensive bladder evaluation and whose clinical cases highlight the aim of this study. These patients were identified from the patient populations at the American Family Children's Hospital at University of Wisconsin Hospital and Clinics, and at the Riley Hospital for Children at Indiana University Health. No transplant proceeded before patients reached ten kilograms. All patients had cystometrograms to assess their bladder capacity and compliance prior to transplant. No bladders were cycled prior to transplant. Patients A, B, and $\mathrm{C}$ had a living related transplant; patients D and E had cadaveric transplants. All ureteral reimplants were non-tunneled at the time of transplant. All reimplants were stented at the time of transplant.

\section{Results}

\section{Patient A}

Three year old male with history of renal failure at birth secondary to severe obstructive uropathy from posterior urethral valves who had several amnio-infusions antenatally both to assess fetal anatomy and to facilitate shunt placement. No shunt was successfully placed. Patient was delivered preterm at 35 weeks gestation and with severe pulmonary hypoplasia and 
peritoneal dialysis dependency until he underwent a simultaneous living donor renal transplantation and diverting vesicostomy at 20 months of age. Patient weighed $10.7 \mathrm{~kg}$ at the time of transplant and was the only patient that was anuric prior to transplant. Patient was the smallest size at the time of transplant in the group. Post-operatively, patient had persistent grade 3 hydronephrosis for which he initially underwent revision of vesicostomy 2 months after the transplant and balloon dilation of his uretero-vesical junction anastomosis 3 months after the transplant. Patient also had an episode of Haemophilus parainfluenzae UTI at 1 month after transplant but this resolved with an appropriate antibiotic course. Patient is no longer dialysis dependent; his creatinine levels have been normal on several follow-up visits. He still however has persistent grade 2 hydronephrosis. Patient's transplant occurred 12 months ago.

\section{Patient B}

Three year old male with history of renal failure (but without need for dialysis) secondary to Eagle-Barrett syndrome who underwent a simultaneous living donor renal transplantation and diverting vesicostomy at 24 months of age. His post-operative course has been relatively unremarkable - creatinine levels have been normal and no reports of UTI, transplant rejection, or need for revision of the vesicostomy. Patient's transplant occurred 12 months ago.

\section{Patient $C$}

Thirty-four month old male with history of renal failure at birth secondary to posterior urethral valves with persistent chronic kidney disease, despite having undergone bilateral end 
cutaneous ureterostomy for upper tract diversion at 6 days of age, and eventually underwent excision of end cutaneous ureterostomies and simultaneous living donor renal transplantation and diverting vesicostomy at 26 months of age. His vesicostomy was placed into the previous left end cutaneous ureterostomy site because the transplant surgeons needed to incise all the way to the pubis to reimplant into the small contracted bladder. Patient had bilateral nephrectomy with excision of ureters at the time of transplant. His post-operative course has also been relatively unremarkable - normal creatinine levels, no UTIs, transplant rejection, or need for further surgical revisions. Patient's transplant occurred 3 months ago.

\section{Patient D}

Five year old male with history of renal failure at birth secondary to posterior urethral valves. Patient had serial bladder taps in-utero, and peritoneal dialysis catheter placed within first month of birth as well as being ventilator dependent for the first few months of life due to pulmonary hypoplasia. Bladder was subsequently managed with vesicostomy but patient continued to have ongoing peritoneal dialysis dependency. Patient was also diagnosed with hepatoblastoma and he subsequently underwent liver resection and bilateral native nephrectomies, followed by subsequent transplantation of liver and kidneys in 2016. Ureteroneocystostomy of transplant ureters were performed onto the native bladder that in turn continued to drain via vesicostomy. Patient's post-operative course has also been relatively unremarkable - normal creatinine levels, no UTIs, transplant rejection, or need for further surgical revisions. Patient's transplant occurred 16 months ago. 


\section{Patient E}

Ten year old male who was born with posterior urethral valves and bilateral high grade vesicoureteral reflux with severe renal insufficiency, but without need for immediate dialysis

who underwent early vesicostomy due to small infant size at birth. However, patient continued to have progressive renal insufficiency requiring peritoneal dialysis within first year of age and subsequently underwent transurethral resection valve and closure of vesicostomy. On subsequent follow-up, patient showed non-functioning right kidney and a poorly function left kidney and was subsequently placed on the transplant list. Similar to patient D, this patient was also diagnosed with hepatoblastoma at 5 years of age and was initiated on chemotherapy. Due to concern for poorly compliant bladder as well as need for ongoing chemotherapy, augmentation of the bladder was not a viable option. Eventually, patient underwent liver resection and bilateral native nephrectomies with bilateral cadaveric renal transplant into native bladder with creation of vesicostomy at 7 years of age. Patient is currently stable with no hydronephrosis, and is awaiting bladder augmentation. Patient's transplant occurred 64 months ago. 


\begin{tabular}{|c|c|c|c|c|c|}
\hline Cause of renal failure & Posterior Urethral Valves & $\begin{array}{c}\text { Eagle-Barrett } \\
\text { syndrome }\end{array}$ & Posterior Urethral Valves & $\begin{array}{c}\text { Posterior } \\
\text { Urethral Valves }\end{array}$ & $\begin{array}{l}\text { Posterior } \\
\text { Urethral } \\
\text { Valves }\end{array}$ \\
\hline Antenatal interventions & $\begin{array}{l}\text { Amnio-infusions; Attempted } \\
\text { bladder shunt }\end{array}$ & None & None & None & None \\
\hline $\begin{array}{c}\text { Pulmonary } \\
\text { hypoplasia/ventilator } \\
\text { dependency }\end{array}$ & $\begin{array}{l}\text { Yes. ventilation dependency } \\
\text { until age } 24 \text { months, requiring } \\
\text { tracheostomy }\end{array}$ & $\begin{array}{l}\text { Ventilator } \\
\text { dependence for } \\
\text { the first few } \\
\text { months of life }\end{array}$ & None & $\begin{array}{l}\text { Yes, Ventilator } \\
\text { dependence for } \\
\text { first few months } \\
\text { of life }\end{array}$ & None \\
\hline Dialysis dependency & $\begin{array}{c}\text { Yes, was on peritoneal dialysis } \\
\text { until transplantation }\end{array}$ & No & No & $\begin{array}{c}\text { Yes, Peritoneal } \\
\text { Dialysis }\end{array}$ & $\begin{array}{c}\text { Yes, } \\
\text { Peritoneal } \\
\text { Dialysis }\end{array}$ \\
\hline $\begin{array}{c}\text { Age at transplantation to } \\
\text { diverted vesicostomy }\end{array}$ & 20 months & 24 months & 26 months & 46 months & 61 months \\
\hline $\begin{array}{l}\text { Pre-transplant bladder } \\
\text { capacity and compliance }\end{array}$ & 30mL; poorly compliant & $\begin{array}{c}\text { 45mL; poorly } \\
\text { compliant }\end{array}$ & $10 \mathrm{~mL}$; poorly compliant & $\begin{array}{c}72 \mathrm{~mL} \text {; poorly } \\
\text { compliant }\end{array}$ & $\begin{array}{l}26 \mathrm{~mL} \text {; poor } \\
\text { compliance }\end{array}$ \\
\hline $\begin{array}{c}\text { Follow-up in months since } \\
\text { transplant }\end{array}$ & 12 months & 12 months & 3 months & 16 months & 64 months \\
\hline $\begin{array}{c}\text { Creatinine prior to } \\
\text { transplant }\end{array}$ & $3.6-5.6$ & $2.2-3.3$ & $1.9-2.8$ & 4.08 & $3.2-3.7$ \\
\hline $\begin{array}{c}\text { Creatinine range during } \\
\text { follow-up period }\end{array}$ & $0.17-0.36$ & $0.13-0.38$ & $0.17-0.34$ & 0.35 & $0.30-0.53$ \\
\hline $\begin{array}{c}\text { Episodes of UTI since } \\
\text { transplant }\end{array}$ & Yes, multiple & None & $\begin{array}{c}\text { Yes, E.coli pyelonephritis } \sim 2 \\
\text { months after transplant }\end{array}$ & None & None \\
\hline $\begin{array}{c}\text { Evidence of transplant } \\
\text { rejection }\end{array}$ & $\begin{array}{l}\text { Banff Type IA acute T-cell } \\
\text { mediated rejection noted } \sim 2 \\
\text { months after transplant; but has } \\
\text { had multiple subsequent } \\
\text { biopsies negative for rejection }\end{array}$ & None to date & None to date & None & None \\
\hline $\begin{array}{l}\text { Surgical revision of } \\
\text { vesicostomy or any } \\
\text { subsequent procedures }\end{array}$ & $\begin{array}{c}\text { Yes, revision of vesicostomy } 2 \\
\text { months after transplant \& } \\
\text { balloon dilation of UVJ } \\
\text { anastomosis } 3 \text { months after } \\
\text { transplant }\end{array}$ & None & $\begin{array}{l}\text { None after the } \\
\text { transplant/vesicostomy but patient } \\
\text { had bilateral end cutaneous } \\
\text { ureterostomies done at } 6 \text { days of } \\
\text { age }\end{array}$ & None & None \\
\hline
\end{tabular}




\section{Discussion}

There are an increasing number of patients who are born in renal failure that still survive, some are anephric or have severe obstructive lesions and oligohydramnios. Moreover, they seem to have relatively normal development and good outcomes. The challenges of dialysis in infants and impact of renal failure at this age argue for early renal transplantation. Several papers have recently been published urging the need to revisit the issue of transplantation into a diverted urinary system. Historically, pediatric transplants were not performed into diverted urinary systems, with children instead undergoing undiversion surgeries prior to transplantation due to anecdotal concerns for increased risks for infection, and as such, decreased graft survival. As evidenced by this case series and others that have already been published, this widely held notion of pretransplant undiversion is being challenged [7] [8] [9]. Vesicostomy allows for earlier less complicated transplant operations. Bowel mobilization and resection for bladder augmentation in young infants undergoing living related transplant into the abdomen complicate an already complicated tight abdominal closure.

Vesicostomies are an especially attractive option to manage high urinary output that occurs post-transplant in infants that require an adult kidney. Vesicostomy is a relatively easy surgery to perform either prior to or during the transplant, and is easy to take care of from the perspective of the family members who must take care of the newborn transplant patient. Furthermore, a vesicostomy does not preclude bladder augmentation in the future when the child is older and augmentation appropriate. Other options like end cutaneous transplant ureterostomy with a high stomal stenotic rate, and ileal loop with similar potential complications as primary ileal augmentation are less optimal options. 
Although not the main focus of this article, it is also important to point out that recent advances in antenatal management such as amnio-infusion for oligohydramnios have made significant impacts in pulmonary and renal management of this patient population over recent years. Two of the five children in this case series had some form of antenatal intervention such as serial bladder taps and amnio-infusions.

Chinnakotla, et al. demonstrate that success rates in pediatric kidney transplantations have been improving remarkably, with increased graft survival in kidneys from both living and deceased donors. This indicates that pre-emptive transplantation from a living donor "continues to be superior and should be the choice in children with end-stage renal disease" [10], further demonstrating the need to update transplantation guidelines in these patients. Long-term survival will need to be monitored as recent evidence suggests average life expectancy was only 33 years [9].

Fetal pulmonary and renal development are co-dependent; as a result, many of these children have pulmonary issues such as pulmonary hypoplasia that necessitate prolonged ventilator dependency and tracheostomy. Similar to advances in renal management, the advances to pulmonary management have also resulted in increased survival of this group. There is a need for a paradigm shift in regards to antenatal and postnatal management of these children, many of whom previously did not survive [2] [11].

Two of the patients included in this review underwent transplant into a diverted bladder because of the risk associated with bladder augmentation while undergoing chemotherapy and transplant immunotherapy. Other potential contraindications for augmentation cystoplasty include inflammatory bowel disease, severe renal insufficiency, and patients with a short life expectancy. 
This study is limited by the short follow up and small patient sample, but the paper documents the early success of transplantation into a diverted system. Recent emphasis has been placed on bladder cycling and early cycling may be a viable alternative. We noted because of the close post-operative observation, our patients with vesicostomies actually had bladder filling and cycling.

\section{Conclusion}

This report, while it has limitations given its inherent nature as a case series, provides further support for the use of vesicostomy as an option for surgical management of patients with renal failure with oligohydramnios and severe obstructive lesions identified antenatally. It also indicates the need to update the criteria for antenatal management of oligohydramnios in obstructive and anephric patients.

\section{Funding}

This research did not receive any specific funding from any source.

\section{Conflict of Interest}

The authors hereby state that they hold no conflicts of interest to disclose. 


\section{References}

1. Seattle Times. Survival of Rep. Herrera Beutler's child a celebrated case study. https://www.seattletimes.com/seattle-news/survival-of-rep-herrera-beutlerrsquos-child-a-celebratedcase-study/ [Accessed December 31 $\left.{ }^{\text {st }}, 2017\right]$

2. Polzin WJ, Lim FY, Habli M, Van Hook J, Minges M, Jaekle R, et al. Use of an amnioport to maintain amniotic fluid volume in fetuses with oligohydramnios secondary to lower urinary tract obstruction or fetal renal anomalies. Fetal Diagnosis and Therapy. 2017;41(1):51-57. doi: $10.1159 / 000445946$.

3. Vvan Stralen KJ, Borzych-Duzalka D, Hataya H, Kennedy SE, Jager KJ, Verrina E, et al. Survival and clinical outcomes of children starting renal replacement therapy in the neonatal period. Kidney Int 2014;86:168e 74 .

4. Carey WA, Martz KL, Warady BA. Outcome of patients initiating chronic peritoneal dialysis during the first year of life. Pediatrics 2015;136:e615e22.

5. Van Arendonk KJ, Boyarsky BJ, Orandi BJ, et al. National trends over 25 years in pediatric kidney transplant outcomes. Pediatrics. 2014;133:594-601..

6. Christman MS, Canning DA, Schast AP, Baluarte HJ, Kaplan BS. Renal transplantation into a diverted urinary system-is it safe in children? J Urol. 2013.

7. Kemper MJ, Mueller-Wiefel DE. Prognosis of antenatally diagnosed oligohydramnios of renal origin. Eur J Pediatr. 2007.

8. Adams J, Mehls O, Wiesel M. Pediatric renal transplantation and the dysfunctional bladder. Transplantation Int. 2004.

9. Serrano OK, Bangdiwala AS, Vock DM, et al. Post-Transplant Malignancy after Pediatric Kidney Transplantation: Retrospective Analysis of Incidence and Risk Factors in 884 Patients Receiving Transplants Between 1963 and 2015 at the University of Minnesota. J Amer Coll of Surgeons. 2017;225(2):181-193. 
10. Outcomes and Risk Factors for Graft Loss: Lessons Learned from 1,056 Pediatric Kidney Transplants at the University of Minnesota. J Amer Coll of Surgeons. 2017;224(4):486-488. doi: http://dx.doi.org/10.1016/j.jamcollsurg.2016.12.027

11. Farrugia MK, Braun MC, Peters CA, Ruano R, Herndon CD. Report on The Society for Fetal Urology panel discussion on the selection criteria and intervention for fetal bladder obstruction. $J$ Pediatr Urol. 2017. 


\begin{tabular}{|c|c|c|c|c|c|}
\hline & $\mathbf{A}$ & $\mathbf{B}$ & $\mathbf{C}$ & D & $\mathbf{E}$ \\
\hline Cause of renal failure & Posterior Urethral Valves & $\begin{array}{l}\text { Eagle-Barrett } \\
\text { syndrome }\end{array}$ & Posterior Urethral Valves & $\begin{array}{c}\text { Posterior } \\
\text { Urethral Valves }\end{array}$ & $\begin{array}{l}\text { Posterior } \\
\text { Urethral } \\
\text { Valves } \\
\end{array}$ \\
\hline Antenatal interventions & $\begin{array}{l}\text { Amnio-infusions; Attempted } \\
\text { bladder shunt }\end{array}$ & None & None & None & None \\
\hline $\begin{array}{c}\text { Pulmonary } \\
\text { hypoplasia/ventilator } \\
\text { dependency }\end{array}$ & $\begin{array}{l}\text { Yes. Ventilation dependency } \\
\text { until } 24 \text { months, requiring } \\
\text { tracheostomy }\end{array}$ & $\begin{array}{l}\text { Ventilator } \\
\text { dependence for } \\
\text { the first few } \\
\text { months of life }\end{array}$ & None & $\begin{array}{c}\text { Yes, Ventilator } \\
\text { dependence for } \\
\text { first few months } \\
\text { of life }\end{array}$ & None \\
\hline Dialysis dependency & $\begin{array}{c}\text { Yes, was on peritoneal dialysis } \\
\text { until transplantation }\end{array}$ & No & No & $\begin{array}{l}\text { Yes, Peritoneal } \\
\text { Dialysis }\end{array}$ & $\begin{array}{l}\text { Yes, } \\
\text { Peritoneal } \\
\text { Dialysis }\end{array}$ \\
\hline \begin{tabular}{|c|}
$\begin{array}{c}\text { Age at transplantation to } \\
\text { diverted vesicostomy }\end{array}$ \\
\end{tabular} & 20 months & 24 months & 26 months & 46 months & 61 months \\
\hline $\begin{array}{c}\text { Pre-transplant bladder } \\
\text { capacity and compliance }\end{array}$ & 30mL; poorly compliant & $\begin{array}{l}45 \mathrm{~mL} ; \text { poorly } \\
\text { compliant }\end{array}$ & 10mL; poorly compliant & $\begin{array}{l}72 \mathrm{~mL} ; \text { poorly } \\
\text { compliant }\end{array}$ & $\begin{array}{l}26 \mathrm{~mL} \text {; poor } \\
\text { compliance }\end{array}$ \\
\hline $\begin{array}{c}\text { Follow-up in months since } \\
\text { transplant }\end{array}$ & 12 months & 12 months & 3 months & 16 months & 64 months \\
\hline $\begin{array}{c}\text { Creatinine prior to } \\
\text { transplant }\end{array}$ & $3.6-5.6$ & $2.2-3.3$ & $1.9-2.8$ & 4.08 & $3.2-3.7$ \\
\hline $\begin{array}{c}\text { Creatinine range during } \\
\text { follow-up period }\end{array}$ & $0.17-0.36$ & $0.13-0.38$ & $0.17-0.34$ & 0.35 & $0.30-0.53$ \\
\hline $\begin{array}{c}\text { Episodes of UTI since } \\
\text { transplant }\end{array}$ & Yes, multiple & None & $\begin{array}{c}\text { Yes, E.coli pyelonephritis } \sim 2 \\
\text { months after transplant }\end{array}$ & None & None \\
\hline
\end{tabular}




\begin{tabular}{|c|c|c|c|c|}
\hline $\begin{array}{c}\text { Evidence of transplant } \\
\text { rejection }\end{array}$ & $\begin{array}{c}\text { Banff Type IA acute T-cell } \\
\text { mediated rejection noted 2 } \\
\text { months after transplant; but has } \\
\text { had multiple subsequent } \\
\text { biopsies negative for rejection }\end{array}$ & None to date & None to date & None \\
\hline $\begin{array}{c}\text { Surgical revision of } \\
\text { vesicostomy or any } \\
\text { subsequent procedures }\end{array}$ & $\begin{array}{c}\text { Yes, revision of vesicostomy 2 } \\
\text { months after transplant \& } \\
\text { balloon dilation of UVJ } \\
\text { anastomosis 3 months after } \\
\text { transplant }\end{array}$ & None & $\begin{array}{c}\text { None after the } \\
\text { transplant/vesicostomy but patient } \\
\text { had bilateral end cutaneous } \\
\text { ureterostomies done at } 6 \text { days of } \\
\text { age }\end{array}$ & None \\
\hline
\end{tabular}

